\title{
Statistical assessment of feeding corn with higher oil content to piglets in the starter phase
}

\author{
M.A.A. Silva1, P.L.O. Carvalho², D. Paiano ${ }^{3}$, M.A. Silva ${ }^{1}$, J.L. Genova2" \\ M.A. Grando² \& S.T. Carvalho² \\ ${ }^{1}$ Animal Science Department, Universidade Estadual do Norte do Paraná, Bandeirantes, PR 86360-000, Brazil \\ ${ }^{2}$ Animal Science Department, Universidade Estadual do Oeste do Paraná, Marechal Cândido Rondon, PR 85960-000, \\ Brazil \\ ${ }^{3}$ Animal Science Department, Universidade do Estado de Santa Catarina, Chapecó, SC 89815-630, Brazil
}

(Received 6 October 2020; Accepted 23 June 2021; Published 29 July 2021)

\begin{abstract}
The aim of this study was to assess the digestibility coefficients (DC) of corn [maize] with an oil content above $3.46 \%$ and its effects on the performance of piglets when fed as dry grain (DG) and as rehydrated corn grain silage (RCGS). In Experiment I, 15 piglets $(22.51 \pm 2.39 \mathrm{~kg})$ were allocated to a reference diet $(R D)$ and to two test diets in which corn in the RD was replaced with DG or RCGS. There were five replications of each treatment. Experiment II involved 36 piglets $(14.76 \pm 2.72 \mathrm{~kg})$, which were assigned to a control diet with common corn grain and to diets in which DG or RCGS replaced the common corn. There were six replications of each treatment. Data were analysed with four statistical models. Model 1 included only the effect of treatment. Model 2 was similar to Model 1 but included initial bodyweight as a covariate. Model 3 was similar to model 1 but included the interaction of diet and period. Model 4 was similar to Model 3 but included the covariate. The more complicated models were generally preferred to Model 1 as they controlled more of the nuisance variation. Feeding a diet that contained RCGS reduced feed intake and improved feed conversion ratio (FCR).
\end{abstract}

Keywords: alternative linear models, digestibility, energetic value, growth, swine

${ }^{\#}$ Corresponding author: jansllerg@gmail.com

\section{Introduction}

Common dry corn is the customary source of dietary energy for feeding pigs. The varieties of corn that are usually used to feed pigs contain between 3.5\% and 9.7\% ether extract (EE) (Adeola \& Bajjalieh, 1997; Silva et al., 2006; Rostagno et al., 2017). However, varieties of corn with higher oil levels could be an alternative feedstuff, providing increased energy density of the diet (Adeola \& Bajjalieh, 1997) and thereby reducing the cost of production. Corn with higher oil content can be ensiled with fermentation bringing about partial gelatinization of the starch and promoting better enzymatic digestion in the gastrointestinal tract (GIT) (Lopes et al., 2001; Oliveira et al., 2004; Silva et al., 2006). This results from a reduced rate of passage, which consequently allows for improved nutrient digestibility (Adeola \& Bajjalieh, 1997; Park et al., 2012; Jordan et al., 2014; Weng, 2017). The action of digestive enzymes was more efficient in wet silage particles because of the $\mathrm{pH}$ of the content of the GIT (Lopes et al., 2001), which provided more energy (Oliveira et al., 2004), without affecting the nitrogen balance (Silva et al., 2005), ensuring a uniform flow of digesta into GIT (Lopes et al., 2001), and improved the fatty acid composition of the backfat (Capraro et al., 2017).

However, investigations are needed in which experimental error is reduced to evaluate the nutritional aspect of feeding corn with high oil content to pigs (Jacobs et al., 2013). Thus, two studies were conducted to test the hypothesis that partial and total replacement of ground common dry corn with corn containing more than $3.46 \%$ oil (Rostagno et al., 2000), either as dry grain (DG) or as rehydrated corn grain silage (RCGS), will improve the digestibility of dietary components by growing pigs. This hypothesis was tested with four statistical models to examine the potential to control sources of experimental error. 


\section{Material and Methods}

The piglets were managed carefully to avoid unnecessary discomfort. All experimental procedures were approved by the UENP Research Ethics Committee (No. 5055 - CEUA).

In the first trial, 15 crossbred barrow piglets (Landrace $x$ Large White $x$ Duroc) with an initial weight of $22.51 \pm 2.39 \mathrm{~kg}$ were randomly allocated to three treatments. The animals were housed and fed individually in metabolism cages similar to those described by Pekas (1968). Thus, the pig was the experimental unit. The entire experimental period was ten days, consisting of five days to acclimatize to experimental diets and cages, and five days to collect faeces and urine.

The evaluated ingredient was corn that contained approximately $4.9 \%$ EE. It was used as DG or as RCGS to replace the common corn with about 3.5\% EE that was used in the RD. The RD was formulated according to the tables of nutritional requirements published by Rostagno et al. (2000). The grain was harvested until it reached $88 \% \mathrm{DM}$. The grain in the RCGS was ground in a hammer mill with a 10-mm sieve and then water was added to produce a mixture with $30 \%$ moisture, which was subsequently ensiled in polyethylene drums with capacity of 200 litres.

During the acclimation phase, the pigs were fed the experimental diets in two daily meals, with $55 \%$ at $08 \mathrm{~h} 00$ and $45 \%$ at $16 \mathrm{~h} 00$. The amount of feed provided daily during collection was determined from the acclimation period, based on voluntary consumption and animal metabolic weights $\left(\mathrm{BW}^{0.75}\right)$. The feed was moistened with water ( $20 \%$ by total weight of feed) to avoid waste, to reduce powdery properties, and to improve palatability. After each meal, water was supplied through a fountain in the proportion of $3.0 \mathrm{~mL} / \mathrm{g}$ of feed consumed, calculated for each experimental unit to avoid excess water consumption.

The method of total collection of faeces was used with the addition of $2 \%$ ferric oxide to mark the beginning and end of faecal collection (Zhang \& Adeola, 2017). Faeces were collected daily, weighed, placed in labelled plastic bags, and stored at $-18^{\circ} \mathrm{C}$. After the collection period, faecal samples were thawed, homogenized, weighed on a digital scale, dried in a forced ventilation oven $\left(55^{\circ} \mathrm{C}\right)$, ground in a Wiley-type grinder mill and stored in polyethylene containers. The faecal samples were subsequently analysed to determine the DM, crude protein (CP), EE, starch, organic matter (OM), and gross energy (GE) contents.

Urine was collected daily in plastic buckets containing $20 \mathrm{~mL}$ of $1: 1 \mathrm{HCl}$ to avoid nitrogen volatilization and bacterial proliferation. An aliquot (20\%) was stored in a freezer at $-18^{\circ} \mathrm{C}$.

All analyses of feed, faeces and urine were performed following procedures described by Silva and Queiroz (2002). The GE content in feed, silage, faeces and urine was determined with an adiabatic calorimeter (Parr Instrument Company). The $\mathrm{pH}$ values of the ingredients were determined using the method of Phillip and Fellner (1992). Digestibility DM (DCDM), CP (DCCP), OM (DCOM), GE (DCGE), and gross energy of GE (MCGE) was calculated according to Moreira et al. (1994). Digestible energy and metabolizable energy contents were calculated using the formula from Matterson et al. (1965).

The second trial involved 36 crossbred pigs (18 barrows and 18 females, Landrace $x$ Large White $x$ Duroc) with an initial average BW of $14.76 \pm 2.72 \mathrm{~kg}$. Animals were distributed in a randomized block design with three treatments and six blocks. The animals were penned as pairs (one male and one female). Because treatments were applied to the pairs, they were the experimental units. The animals were housed in an enclosed shed, which contained suspended nursery stalls with polyethylene plastic flooring. The stalls were equipped with feeders and pacifier-type drinking fountains.

The experimental diets (Table 1) were formulated to meet the nutritional requirements of piglets in the nursery phase (Rostagno et al., 2000). There were three dietary treatments, and each diet was formulated to be isocaloric and contain similar amounts of calcium, phosphorus and lysine. The RD contained approximately $63 \%$ common corn grain, which was fully replaced by DG or RCGS. The pH values of the ingredients were determined using the method of Phillip and Fellner (1992).

The animals received feed and water ad libitum throughout the experiment. Average daily feed intake (ADFI) (kg/day), average daily BWG) ( $\mathrm{kg} /$ day), and FCR $(\mathrm{kg} / \mathrm{kg})$ were calculated using the recorded bodyweights of the animals and feed consumption was calculated as the difference between the amount that was provided and leftover feed on the pen floor and in the feeder of each stall.

The data were subjected to preliminary analysis of variance and covariance, and residuals were examined to identify outliers from normal distribution. Those observations with residuals that were greater than or equal to three standard deviations were considered outliers. The normality of the residuals and the homogeneity of variance among treatments were assessed using the Shapiro-Wilk and Levene tests, respectively. 
Table 1 Formulation of diets for nursery pigs using various forms of corn and the chemical composition of those diets, as fed

\begin{tabular}{|c|c|c|c|}
\hline Ingredients & Reference diet & Dry grain-based diet & $\begin{array}{l}\text { Rehydrated corn grain } \\
\text { silage-based diet }\end{array}$ \\
\hline Common corn grain & 62.81 (87.45\% DM) & - & - \\
\hline Dry corn grain & - & 63.25 (90.54\% DM) & - \\
\hline Rehydrated corn grain silage & - & - & 62.39 (87.45\% DM) \\
\hline Soybean meal & 29.67 & 30.02 & 31.23 \\
\hline Soybean oil & 1.09 & 0.30 & - \\
\hline Dicalcium phosphate & 1.76 & 1.72 & 1.74 \\
\hline Calcitic limestone & 0.70 & 0.74 & 0.71 \\
\hline Common salt & 0.40 & 0.40 & 0.40 \\
\hline Sugar & 3.00 & 3.00 & 3.00 \\
\hline Mineral and vitamin premix ${ }^{1}$ & 0.50 & 0.50 & 0.50 \\
\hline L-lysine HCL & 0.07 & 0.06 & 0.02 \\
\hline \multicolumn{4}{|l|}{ Calculated composition } \\
\hline Digestible energy, kcal/kg & 3,400 & 3,400 & 3,400 \\
\hline Crude protein, \% & 18.65 & 18.97 & 19.29 \\
\hline Total lysine, \% & 1.06 & 1.06 & 1.06 \\
\hline Total methionine + cystine, $\%$ & 0.63 & 0.63 & 0.64 \\
\hline Total calcium, \% & 0.83 & 0.83 & 0.83 \\
\hline Available phosphorus, \% & 0.43 & 0.43 & 0.43 \\
\hline
\end{tabular}

${ }^{1}$ Content per $\mathrm{kg}$ of diet: vitamin $\mathrm{A}: 2,000,000 \mathrm{IU}$; vitamin $\mathrm{D}_{3}: 400,000 \mathrm{IU}$; vitamin $\mathrm{E}: 5,000 \mathrm{IU}$; vitamin $\mathrm{K}_{3}: 400.0 \mathrm{mg}$; vitamin $B_{1}: 400.0 \mathrm{mg}$; vitamin $B_{2}: 1,200.0 \mathrm{mg}$; vitamin $B_{6}: 600.0 \mathrm{mg}$; vitamin $B_{12}: 6,000.0$ mcg; nicotinic acid: $6,000.0 \mathrm{mg}$; pantothenic acid: 2,400.0 mg; biotin: $20.0 \mathrm{mg}$; folic acid: $200.0 \mathrm{mg}$; selenium: $60.0 \mathrm{mg}$; choline: $30.0 \mathrm{~g}$; lysine: $234.0 \mathrm{~g}$; salinomycin: 10,000.0 mg; antioxidant: $20.0 \mathrm{~g}$; iodine: $300.0 \mathrm{mg}$; cobalt: $200.0 \mathrm{mg}$; copper: 35,000,0 mg; zinc: $20,000.0$ mg; iron: 20,000.0 mg; manganese: $8,000.0 \mathrm{mg}$

Four linear models were used to analyse the data. Model 1 was:

$$
Y_{i j k}=m+T_{i}+P_{j}+\varepsilon_{i j k}
$$

where: $Y_{\mathrm{ijk}}=$ an average observation of the dependent variable from the kth experimental unit;

$\mathrm{m}=$ effect of the overall mean common to all observations;

$\mathrm{T}_{\mathrm{i}}=$ effect of ith diet, $\mathrm{i}=(1,2$; trial 1$)$ or $(1,2,3$; trial 2$)$;

$P_{j}=$ period effect, for $\mathrm{j}=(1$ and 2$)$;

$\varepsilon_{\mathrm{ijk}}=$ random error.

The other three models included additional terms to control nuisance variation. Model 2 was:

$$
Y_{i j k}=m+T_{i}+P_{j}+\beta\left(X_{i j k}-\bar{X}_{\ldots}\right)+\varepsilon_{i j k}
$$

where, in addition to the effects identified for Model 1, the linear effect of initial bodyweight (trial 1) or average initial bodyweight (trial 2) was fit as a covariate where $\beta=$ the regression coefficient of the dependent variable on initial weight; $X_{\mathrm{ijk}}=$ initial bodyweight of the experimental unit; and $\bar{X}_{\ldots}=$ the mean of the covariate. Model 3 was:

$$
Y_{i j k}=m+T_{i}+P_{j}+P_{i j}+\varepsilon_{i j k}
$$

where, in addition to the effects identified for Model 1, the interaction effect between treatment and period was added to the model. Model 4 was: 


$$
\mathrm{Y}_{\mathrm{ijk}}=\mathrm{m}+\mathrm{T}_{\mathrm{i}}+\mathrm{P}_{\mathrm{j}}+\mathrm{TP}_{\mathrm{ij}}+\beta\left(\mathrm{X}_{\mathrm{ijk}}-\bar{X}_{\ldots}\right)+\varepsilon_{\mathrm{ijk}}
$$

and contained both the linear covariate for initial bodyweight and the interaction of treatment with period. Analyses of variance were conducted for each of the four models using the GLM procedure of SAS (SAS Institute Inc., Cary, North Carolina, USA). Treatment means were compared with Student's t test at a 5\% probability when the overall treatment effect was significant. Values of the Akaike information criterion were obtained using the MIXED procedure to analyse the data. Power calculations helped to explain treatment effects that were not detectably different at the $5 \%$ level of significance, but were different at the $10 \%$ level. Post-hoc power calculations were performed using power.anova.test of $R$ (R Core Team, 2017).

\section{Results and Discussion}

The proximate analysis of ingredients that were used in the digestibility trial is presented in Table 2. These ingredients may differ from values in previous studies owing to factors such as the genetic potential of the seeds, level of fertilization, soil fertility, climatic conditions, type of processing, time of harvest, and stage of physiological maturity of the plant (Åkerfeldt et al., 2019). In the present study, the CP and EE levels for the dry and ensiled corn grain were greater than the reference values in EMBRAPA (1991), whether on an as-fed basis or corrected for $87.45 \%$ of DM.

Table 2 Proximate analysis of the dry grain and rehydrated ensiled corn grain express on an as-fed basis and a constant $87.45 \%$ dry matter

\begin{tabular}{lcccc}
\hline & \multicolumn{2}{c}{ As fed } & \multicolumn{2}{c}{$87.45 \%$ dry matter } \\
\hline Nutrient & Dry grain & $\begin{array}{c}\text { Rehydrated corn } \\
\text { grain silage }\end{array}$ & Dry grain & $\begin{array}{c}\text { Rehydrated corn } \\
\text { grain silage }\end{array}$ \\
\hline Dry matter, \% & & & & \\
Crude protein, \% & 88.60 & 61.52 & 87.45 & 87.45 \\
Organic matter, \% & 9.24 & 6.37 & 9.12 & 9.05 \\
Ether extract, \% & 87.28 & 60.56 & 86.14 & 86.08 \\
Ash, \% & 4.92 & 3.26 & 4.85 & 4.63 \\
Gross energy, kcal/kg & 1.32 & 0.96 & 1.30 & 1.37 \\
Digestible energy, kcal/kg & 3,972 & 2,802 & 3,971 & 3,984 \\
Metabolizable energy, kcal/kg & 3,551 & 2,592 & 3,550 & 3,685 \\
pH & 3,429 & 2,412 & 3,428 & 3,430 \\
& 5.82 & 4.21 & & - \\
\hline
\end{tabular}

The GE values in the present study were slightly lower than those observed by Rostagno et al. (2017), who used corn grain silage made from corn with a higher oil content than the corn that was used in this study. However, the EE content of corn in the present study was $1.1 \%$ higher than common dry corn (Rostagno et al., 2017).

The $\mathrm{pH}$ value obtained for RCGS was 4.21 , which is close to the values reported by Lopes et al. (2001), who obtained a result of 3.8 from providing wet grain silage for pigs. The $\mathrm{pH}$ of an ingredient or diet affects the physiological processes of animal metabolism directly, such as enzyme activity, which can affect the digestion and absorption of nutrients, and determine the gastric retention time and homogeneous flow of the digesta to the small intestine in the interval of the meals (Silva et al., 2006), which contributed to the improvement of digestibility coefficients in piglets that received RCGS.

The difference between DG and RCGS for DCDM was detected with a $P$-value between 0.04 and 0.07 , depending on the model (Table 3 ). This effect on DCGE was also highly significant $(P<0.01)$ across all of the models. There was also a difference $(P=0.099)$ in the forms of corn used in the diet for the DCOM, which was detected with Model 4 . Thus, RCGS-fed piglets showed higher digestibility coefficients for DM, GE and OM compared with those that received DG. 
Table 3 Apparent digestibility of dry matter, crude protein, organic matter and gross energy of diets containing dry corn and rehydrated ensiled corn for piglets in the starter phase

\begin{tabular}{llllll}
\hline \multirow{2}{*}{ Statistic } & \multicolumn{5}{c}{ Coefficients } \\
\cline { 2 - 6 } & DCDM & DCCP & DCOM & DCGE & MCGE \\
\hline DG mean $(\mathrm{N}=5)$ & 91.8 & 87.8 & 92.1 & 89.4 & 86.3 \\
RCGS mean $(\mathrm{N}=5)$ & 93.8 & 88.5 & 93.4 & 92.5 & 86.1 \\
RMSE & & & & & \\
Model 1 & 1.337 & 2.956 & 1.206 & 1.173 & 5.705 \\
Model 2 & 1.410 & 3.160 & 1.249 & 1.212 & 5.960 \\
Model 3 & 1.208 & 3.129 & 1.170 & 1.178 & 5.935 \\
Model 4 & 1.260 & 3.380 & 1.195 & 1.209 & 6.288 \\
CV & & & & & \\
Model 1 & 1.44 & 3.35 & 1.30 & 1.29 & 6.62 \\
Model 2 & 1.52 & 3.58 & 1.34 & 1.33 & 6.91 \\
Model 3 & 1.30 & 3.55 & 1.26 & 1.29 & 6.89 \\
Model 4 & 1.36 & 3.83 & 1.29 & 1.33 & 7.29 \\
P-value & & & & & \\
Model 1 & 0.059 & 0.756 & 0.141 & 0.003 & 0.922 \\
Model 2 & 0.072 & 0.775 & 0.130 & 0.004 & 0.782 \\
Model 3 & 0.035 & 0.802 & 0.114 & 0.003 & 0.979 \\
Model 4 & 0.042 & 0.828 & 0.099 & 0.006 & 0.852
\end{tabular}

1DCDM: dry matter digestibility, DCCP: crude protein digestibility, DCOM: organic matter digestibility, DCGE: gross energy digestibility, MCGE: gross energy metabolizability, DG: dry grain, RCGS: rehydrated corn grain silage, Model 1: model including only treatment and period main effects, Model 2: Model 1 plus initial bodyweight covariate, Model 3: Model 1 plus interaction of diet and period, Model 4: Model 3 plus initial bodyweight covariate, RMSE: root mean square error, CV: coefficient of variation

Model 4 was the most complete model in analysing these data. However, it did not always produce the smallest root mean square error (RMSE) and thus was not consistently the most sensitive for detecting differences between the treatments. The post-hoc power of the test results mirrored those of the RMSE, whereby the smallest RMSE produced the greatest power (Table 4). In general, the greatest statistical power was achieved when the interaction of period and treatment was included in the model. The conclusion that these models were most appropriate for these data was supported by their having the smallest Akaike information criteria statistic (Table 4).

Table 5 shows the effects of using digestibility coefficients from period 1 as covariates in analyses of data from period 2. With the exception of the GE metabolizability coefficient from period I, which influenced $(P \leq 0.01)$ the DCDM, DCCP, DCOM, and DCGE values that were observed in period 2, the choice of covariate made little difference in the outcome of the statistical analyses of these data.

Wet corn silage suffers disruption of the protein matrix, in addition to the exposure of starch granules in the ensiling process, which can promote increased digestibility (Lopes et al., 2001). The DCGE, MCGE and DCCP obtained from RCGS were similar to the values reported by Oliveira et al. (2004), who tested wet corn grain silage for barrows and obtained results of $90.91 \%$ for DCGE, $88.54 \%$ for MCGE, and $87.82 \%$ for DCCP.

The digestibility of a dietary ingredient can be affected by the type and intensity of processing involved in its production. With diets made from coarse materials, pigs can select the more desirable parts (Åkerfeldt et al., 2019). This selection among ingredients of a mixed ration can lead to large differences in estimates of its digestibility. Also, with the increase in age and development of the GIT, there can be an increase in the estimated digestibility for some nutrients, including EE and CP (Noblet \& Shi, 1994). 
Table 4 Post-hoc power of the test and Akaike information criteria for statistical models used to analyse digestibility coefficients of diets dry corn and rehydrated ensiled corn for piglets in the starter phase

\begin{tabular}{|c|c|c|c|c|c|c|c|c|c|c|c|c|}
\hline \multirow{3}{*}{ Coefficients } & \multicolumn{8}{|c|}{ Power of the test $(1-\beta)$} & \multirow{2}{*}{\multicolumn{4}{|c|}{ Akaike information criteria }} \\
\hline & \multicolumn{4}{|c|}{$\alpha=0.05$} & \multicolumn{4}{|c|}{$\alpha=0.10$} & & & & \\
\hline & M1 & M2 & M3 & M4 & M1 & M2 & M3 & M4 & M1 & M2 & M3 & M4 \\
\hline DCDM & 61.20 & 56.71 & 69.91 & 66.30 & 74.81 & 70.87 & 81.97 & 79.09 & 106.4 & 107.7 & 101.2 & 102.4 \\
\hline DCCP & 6.94 & 7.70 & 6.73 & 6.48 & 13.00 & 12.62 & 12.67 & 12.29 & 119.1 & 119.0 & 114.5 & 114.2 \\
\hline DCOM & 40.28 & 38.05 & 42.33 & 40.88 & 54.81 & 52.43 & 56.96 & 55.45 & 104.8 & 106.0 & 100.8 & 101.8 \\
\hline DCGE & 98.34 & 97.73 & 98.26 & 97.78 & 99.51 & 99.28 & 99.48 & 99.30 & 104.4 & 105.6 & 100.9 & 101.9 \\
\hline MCGE & 5.05 & 5.04 & 5.05 & 5.04 & 10.08 & 10.07 & 10.07 & 10.06 & 129.7 & 127.9 & 123.5 & 121.7 \\
\hline
\end{tabular}

M: model; DCDM: dry matter digestibility, DCCP: crude protein digestibility, DCOM: organic matter digestibility, DCGE: gross energy digestibility, MCGE: gross energy metabolizability, DG: dry grain, RCGS: rehydrated corn grain silage, Model 1: model including only treatment and period main effects, Model 2: Model 1 plus initial bodyweight covariate, Model 3: Model 1 plus interaction of diet and period, Model 4: Model 3 plus initial bodyweight covariate, RMSE: root mean square error, CV: coefficient of variation

Table 5 Significance and coefficients of variation of apparent digestibility and metabolizability coefficients of gross energy using the values of period I as covariate criteria for period II

\begin{tabular}{|c|c|c|c|c|c|c|c|c|c|c|}
\hline \multirow{3}{*}{$\begin{array}{l}\text { Response } \\
\text { observed } \\
\text { in period } 2\end{array}$} & \multicolumn{10}{|c|}{ Covariate from period 1} \\
\hline & \multicolumn{5}{|c|}{ Coefficient of variation, $\%$} & \multicolumn{5}{|c|}{$P$-value } \\
\hline & DCDM & $\mathrm{DCCP}$ & DCOM & DCGE & MCGE & DCDM & DCCP & $\mathrm{DCOM}$ & DCGE & MCGE \\
\hline DCDM & 1.37 & 0.69 & 1.37 & 1.31 & 0.36 & 0.881 & 0.133 & 0.921 & 0.695 & 0.035 \\
\hline DCCP & 3.44 & 2.87 & 3.69 & 3.81 & 1.31 & 0.567 & 0.342 & 0.747 & 0.982 & 0.061 \\
\hline DCOM & 1.21 & 0.60 & 1.21 & 1.13 & 0.23 & 0.948 & 0.129 & 0.868 & 0.631 & 0.017 \\
\hline DCGE & 1.08 & 1.19 & 1.19 & 1.30 & 0.59 & 0.419 & 0.552 & 0.556 & 0.800 & 0.106 \\
\hline MCGE & 6.73 & 8.51 & 7.83 & 8.79 & 5.44 & 0.310 & 0.599 & 0.462 & 0.675 & 0.189 \\
\hline
\end{tabular}

DCDM: dry matter digestibility, DCCP: crude protein digestibility, DCOM: organic matter digestibility, DCGE: gross energy digestibility, MCGE: gross energy metabolizability

The dry grain DCOM (92.1\%) in the current study was close to the value of $90 \%$, which was reported for corn with higher oil content (Rostagno et al., 2017). Silva et al. (2006) evaluated three forms of corn with higher oil content in diets for pigs and found similar values of DCOM to those in the present study. Adeola and Bajjalieh (1997) observed an $8 \%$ to $10 \%$ improvement in feed efficiency and a numerical improvement in weight gain when high-oil corn was fed versus corn that was lower in EE. According to these authors, the increase in dietary fat delayed the digesta flow rate and consequently influenced gastric emptying, with increased digestibility because digestion took longer to occur.

In the present study, various analytical models were used to assess the treatment effects. These models changed the implications that could be drawn from results. Use of covariates in models can reduce the RMSE and thereby change the level of significance and power of the test for the treatment effect. Use of a covariate for initial weight narrowed the inference space to groups of pigs with similar weight at the start of the experiment. Evaluation of the interaction between treatment effects and period tested the similarity of treatment effects across periods. The lack of similar treatment effects across periods could be problematic in determining which treatment was preferable.

Use of covariates to control nuisance variation resulting from differences in the bodyweight of pigs in digestion trials has been reported (Urriola \& Stein, 2010; Jacobs et al., 2013). Jacobs et al. (2013) reported that the use of covariates in digestibility models with pigs in the growing phase could be effective in reducing the error variance, making the significance tests more sensitive. In contrast, including initial bodyweight as a covariate (Model 2) in the present study increased the RMSE for all of the dependent variables. The 
inclusion of the interaction of treatment effect and period (Models 3 and 4) caused little difference in the significance tests. Urriola and Stein (2010) also found no effect of a diet by period interaction for the response variables they analysed, corroborating the present results. Use of IBW as a covariate was justified by the ability to remove nuisance variation associated with differences among pigs and to determine treatment effects more accurately (Noblet \& Van Milgen, 2004; Young et al., 2011; Jacobs et al., 2013). The age of the experimental animals was also proposed as a potential covariate for this reason (Noblet \& Shi, 1994). The present results point to the need to balance the significance threshold ( $\alpha$ ) appropriately with power of the test $(1-\beta)$.

Power of the test revealed the probability that failure to reject the null hypothesis indicated a true lack of difference between the treatments. However, the calculation of the power observed after conducting an experiment must be weighted (Aaron \& Hays, 2004), and is not recommended in all situations. An alternative is to use a priori power calculations to determine the number of experimental units to detect an effect of a size that is believed to be important.

In the feeding trail, the treatment effects on ADFI were significant $(P<0.05)$ with Models 2 and 4 as a consequence of the smaller RMSE when the variation associated with IBW was removed from the error variance with analysis of covariance (Table 6). Feed intake was lower for pigs that were fed RCGS than for pigs fed the control diet and DG. Likewise, treatment effects on gain were detected using Models 2 and 4 with pigs fed the control diet having the fastest rate of gain, followed by DG, and then RCGS. Treatment effects on FCR were detected $(P<0.05)$ with all four statistical models. The pigs fed RCGS were most efficient, followed by those fed the control diet, with the pigs fed DG being least efficient. No differences among treatments in FBW were detected regardless of the statistical model.

Table 6 Results from a feeding trial that evaluated the form in which corn was included in the diet for pigs during the starter phase and analysed with four statistical models

\begin{tabular}{|c|c|c|c|c|c|}
\hline Statistic & IBW, $\mathrm{kg}$ & ADFI, $\mathrm{kg}$ & Gain, $\mathrm{kg}$ & FCR & FBW, $\mathrm{kg}$ \\
\hline Control mean $(\mathrm{N}=6)^{1}$ & 14.20 & 1.44 & 0.75 & 1.91 & 35.59 \\
\hline $\mathrm{DG}$ mean $(\mathrm{N}=6)$ & 15.77 & 1.47 & 0.72 & 2.02 & 33.91 \\
\hline RCGS mean $(\mathrm{N}=6)$ & 14.55 & 1.35 & 0.73 & 1.84 & 32.81 \\
\hline \multicolumn{6}{|l|}{ RMSE } \\
\hline Model 1 & & 0.078 & 0.029 & 0.044 & 1.963 \\
\hline Model 2 & & 0.057 & 0.020 & 0.042 & 0.900 \\
\hline Model 3 & & 0.084 & 0.031 & 0.049 & 2.101 \\
\hline Model 4 & & 0.057 & 0.019 & 0.047 & 0.909 \\
\hline \multicolumn{6}{|l|}{ CV } \\
\hline Model 1 & & 5.56 & 3.99 & 2.33 & 4.16 \\
\hline Model 2 & & 4.06 & 2.72 & 2.23 & 2.72 \\
\hline Model 3 & & 6.00 & 4.29 & 2.57 & 6.36 \\
\hline Model 4 & & 4.05 & 2.69 & 2.46 & 2.75 \\
\hline \multicolumn{6}{|l|}{ P-value } \\
\hline Model 1 & & 0.228 & 0.215 & 0.000 & 0.829 \\
\hline Model 2 & & 0.043 & 0.009 & 0.000 & 0.349 \\
\hline Model 3 & & 0.248 & 0.245 & 0.002 & 0.829 \\
\hline Model 4 & & 0.034 & 0.010 & 0.003 & 0.331 \\
\hline \multicolumn{6}{|l|}{ AIC } \\
\hline Model 1 & & 16.7 & 38.3 & 29.2 & 54.1 \\
\hline Model 2 & & 17.8 & 38.9 & 23.8 & 37.2 \\
\hline Model 3 & & 11.6 & 29.4 & 21.4 & 46.2 \\
\hline Model 4 & & 13.0 & 29.9 & 16.1 & 31.3 \\
\hline
\end{tabular}

1 The experimental unit was a pair of pigs, one barrow and one gilt 
IBW: initial bodyweight, ADFI: average daily feed intake, FCR: feed conversion ratio, FBW: final bodyweight, DG: dry grain, RCGS: rehydrated corn grain silage, Model 1: model including only treatment and period main effects, Model 2: Model 1 plus initial bodyweight covariate, Model 3: Model 1 plus interaction of diet and period, Model 4: Model 3 plus initial bodyweight covariate, RMSE: root mean square error, CV: coefficient of variation

The anaerobic fermentation that occurred during the processing of wet corn grain silage may have produced a product with greater energy availability for pigs than common dry corn grain, which influenced the reduction of ADFI (models 2 and 4) and improvement of FCR. The pH of the control, DG and RCGS diets was $5.75,5.70$, and 5.05 , respectively. Thus, the pH of the RCGS diet may have contributed to the reduction of ADFI and improvement in FCR because the lower pH created an environment that was more favourable to enzymatic activity and the growth of beneficial microorganisms that synthesize short-chain fatty acids (SCFAs).

It may be hypothesized that piglets fed the control diet had greater ADFI and concomitantly higher BWG because the higher EE content of the grain in DG and RCGS promoted satiety (Carter et al., 2017). Moreover, microbial fermentation of fibrous material and material with a larger particle size in the hindgut to produce SCFA produces heat, which can affect the intake of silage (Ảkerfeldt et al., 2019). Greater dissociation of mineral molecules from the diet is promoted by SCFAs, which provide for the formation of chelated mineral complexes, improve the gut health of the animals, and reduce the rate of gastric emptying (Silva et al., 2006).

The improvement of FCR in piglets receiving diets with total replacement of common corn grain with wet corn grain silage was also observed by Oliveira et al. (2004). However, Lopes et al. (2001) analysed the replacement of common corn grain with wet corn grain silage, on a DM basis, and did not observe differences in BWG during the growing phase.

The Akaike information criterion indicated that Model $3, \mathrm{WHICH}$ included the interaction of treatment and period, would be preferred for ADFI and gain (Table 6). Model 4 was nearly the equivalent of Model 3 by this criterion for the analysis of gain and was preferred for the analyses of FCR and FBW. Other assessments of growth performance by pigs included covariates in the statistical models that were used to analyse the data (Oliveira et al., 2018; Genova et al., 2019; Oliveira et al., 2019). Additionally, the use covariates in statistical models to control the experimental error could minimize the number of experimental units required for robust experimentation (Jacobs et al., 2013). Overall, Models 2 and 4 showed greater control of experimental variation and improved the authors' ability to compare means between treatments more accurately.

\section{Conclusions}

Evaluating corn with higher oil content as DG and RCGS in diets for pigs indicated this corn can be considered an alternative ingredient to traditional dry corn. Statistical models that controlled nuisance variation effectively were more likely to produce significant treatment effects.

\section{Acknowledgements}

This study was financed in part by the Coordenação de Aperfeiçoamento de Pessoal de Nível Superior - Brazil (CAPES) - Finance Code 001, and the Fundação Araucária for research support. The authors also appreciate the additional financial support provided by the Universidade Estadual do Norte do Paraná - UENP/PROPG/EDITORA UENP.

\section{Authors' Contributions}

All the authors contributed equally and commented on the early and final versions of the manuscript.

\section{Conflict of Interest Declaration}

There are no conflicts of interest.

\section{References}

Aaron, D.K. \& Hays, V.W., 2004. How many pigs? Statistical power considerations in swine nutrition experiments. J. Anim. Sci. 82 (suppl_13), E245-E254. DOI: 10.2527/2004.8213_supplE245x

Adeola, O. \& Bajjalieh, N.L., 1997. Energy concentration of high-oil corn varieties for pigs. J. Anim. Sci. 75, $430-436$. DOI: $10.2527 / 1997.752430 x$

Åkerfeldt, M.P., Nihlstrand, J., Neil, M., Lundeheim, N., Andersson, H.K. \& Wallenbeck, A., 2019. Chicory and red clover silage in diets to finishing pigs - influence on performance, time budgets and social interactions. Org. Agric. 9, 127-138. DOI: 10.1007/s13165-018-0216-z

Capraro, D., Buccioni, A., Piasentier, E. \& Spanghero, M., 2017. Feeding finishing heavy pigs with corn silages: Effects on backfat fatty acid composition and ham weight losses during seasoning. Ital. J. Anim. Sci. 16, n. 4, 588-592. DOI: 10.1080/1828051X.2017.1302825 
Carter, N.A., Dewey, C.E., Grace, D., Lukuyu, B., Smith, E. \& De Lange, C.F.M., 2017. Average daily gain and the impact of starting bodyweight of individual nursery and finisher Ugandan pigs fed a commercial diet, a foragebased diet, or a silage-based diet. J. Swine Health Prod. 25, 121-128.

EMBRAPA (Empresa Brasileira de Pesquisa Agropecuaria), 1991. Tabela de composição química e valores energéticos de alimentos para suínos e aves. 3rd edition. EMBRAPA-CNPSA, Concórdia SC, Brazil.

Genova, J.L., Carvalho, P.L.D.O., Oliveira, N.T.E.D., Oliveira, A.D.C., Gois, F.D., Castro, D.E.D.S., Souza, F.N.C., Trautenmüller, H., Santos, L.B.D.A.D. \& Leal, I.F., 2019. Partial replacement of soybean meal with different protein sources in piglet feed during the nursery phase. Asian-Australas. J. Anim. Sci. 32, 1725-1733. DOI: 10.5713/ajas.17.0753

Jacobs, B.M., Patience, J.F., Lindemann, M.D., Stalder, K.J. \& Kerr, B.J., 2013. The use of a covariate reduces experimental error in nutrient digestion studies in growing pigs. J. Anim. Sci. 91, 804-810. DOI: 10.2527/jas.20114868

Jordan, K.E., Goncalves, M.A.D., Nemechek, J.E., Dejong, J.A., Tokach, M.D., Goodband, R.D. \& Woodworth, J.C., 2014. Comparison of soybean oil and different sources of corn oil on nursery pig growth performance, Kans. Agric. Exp. Stn. Res. Rep. 0, 47-52. DOI: 10.4148/2378-5977.6908

Lopes, A.B.R.D.C., Berto, D.A., Costa, C., Muniz, M.H.B. \& De Magalhães Rosa, G.J., 2001. Silagem de grãos úmidos de milho para suínos nas fases de crescimento e terminação. B. Ind. Anim. 58, 191-200.

Matterson, L.D., Potter, L.M., Stutz, M.W. \& Singsen, E.P., 1965. The metabolizable energy of feed ingredients for chickens. Agric. Exp. Stn. Res. Rep. 7, 3-11.

Moreira, I., Rostagno, H.S., Coelho, D.T., Costa, P.M.A. \& Tafuri, M.L., 1994. Determinação dos coeficientes de digestibilidade, valores energéticos e índices de controle de qualidade do milho e soja integral processados pelo calor. Rev. Bras. Zootec. 23, 916-929

Noblet, J. \& Shi, X.S., 1994. Effect of bodyweight on digestive utilization of energy and nutrients of ingredients and diets in pigs. Livest. Prod. Sci. 37, 323-338. DOI: 10.1016/0301-6226(94)90126-0

Noblet, J. \& Van Milgen, J., 2004. Energy value of pig feeds: Effect of pig bodyweight and energy evaluation system. J. Anim, Sci. 82(suppl_13), E229-E238. DOI: 10.2527/2004.8213_supplE229x

Oliveira, N.T.E.D., Carvalho, P.L.D.O., Genova, J.L., Caxias Junior, O.A., Cristofori, E.C., Silveira, F.H.R. \& Santana, A.L.A., 2018. Additional effect of coated sodium butyrate $30 \%$ in the piglets feeding during the nursery phase. Semin. Cienc. Agrar. 39, 2771-2782. http://www.uel.br/revistas/uel/index.php/semagrarias/article/view/32669/24594

Oliveira, N.T.E.D., Carvalho, P.L.D.O., Genova, J.L., Cristofori, E.C., Silveira, F.H.R., Caxias Junior, O.A. \& Santana, A.L.A., 2019. Addition of different probiotics to commercial feeds for piglets during the nursery phase. Semin. Cienc. Agrar. 40, 1225-1236. DOI: 10.5433/1679-0359.2019v40n3p1225

Oliveira, R.P., Furlan, A.C., Moreira, I., Fraga, A.L., Bastos, A.O., 2004. Valor Nutritivo e Desempenho de Leitões Alimentados com Rações Contendo Silagem de Grãos Úmidos de Milho. Rev. Bras. Zootec. 33, 146-156. DOI: 10.1590/S1516-35982004000100019

Park, J.C., Kim, S.C., Lee, S.D., Jang, H.C., Kim, N.K., Lee, S.H. \& CHOI, B.H., 2012. Effects of dietary fat types on growth performance, pork quality, and gene expression in growing-finishing pigs. Asian-Australas. J. Anim. Sci. 25, 1759-1767. DOI: 10.5713/ajas.2012.12416

Pekas, J.C., 1968. Versatile swine laboratory apparatus for physiologic and metabolic studies. J. Anim. Sci. 27, 13031309. https://doi.org/10.2527/jas1968.2751303x

Phillip, L.E. \& Fellner, V., 1992. Effects of bacterial inoculation of high moisture ear corn on its aerobic stability, digestion and utilization for growth by beef steers. J. Anim. Sci. 70, 3178-3187. https://doi.org/10.2527/1992.70103178x

Rostagno, H.S., Albino, L.F.T., Donzele, J.L., Gomes, P.C., Ferreira, A.S., Oliveira, R.F. \& Lopes, D.C., 2000. Tabelas brasileiras para aves e suínos: composição de alimentos e exigências nutricionais. 1st edition. UFV, Viçosa MG, Brazil.

Rostagno, H.S., Albino, L.F.T., Hannas, M.I., Donzele, J.L., Sakomura, N.K., Perazzo, F.G., Saraiva, A., Teixeira, M.L., Rodrigues, P.B., Oliveira, R.F., Barreto, S.L.T. \& Brito, C.O., 2017. Tabelas brasileiras para aves e suínos: composição de alimentos e exigências nutricionais. 4th edition. UFV, Viçosa MG, Brazil.

Silva, D.J. \& Queiroz, A.C., 2002. Análise de alimentos (métodos químicos e biológicos). 3rd edition. UFV, Viçosa MG, Brazil.

Silva, A.D.A.D., Marques, B.M.F.P.P., Hauschild, L., Garcia, G.G. \& Lovatto, P.A., 2005. Digestibilidade e balanços metabólicos da silagem de grãos úmidos de milho para suínos. Cienc. Rural. 35, 877-882. DOI: 10.1590/S010384782005000400020

Silva, M.A.A.D., Furlan, A.C., Moreira, I., Paiano, D., Jobim, C.C. \& Barcellos, L.C.G., 2006. Avaliação nutricional do milho com maior teor de óleo, nas formas de grãos secos e silagens, para suínos nas fases de crescimento e terminação. Rev. Bras. Zootec. 35, 830-839. DOI: 10.1590/S1516-35982006000300028

Urriola, P.E. \& Stein, H.H., 2010. Effects of distillers dried grains with solubles on amino acid, energy, and fiber digestibility and on hindgut fermentation of dietary fiber in a corn-soybean meal diet fed to growing pigs. J. Anim. Sci. 88, 1454-1462. DOI: 10.2527/jas.2009-2162

Weng, R.C., 2017. Dietary fat preference and effects on performance of piglets at weaning. Asian-Australas. J. Anim. Sci. 30, 834-842. DOI: 10.5713/ajas.16.0499

Young, J.M., Cai, W. \& Dekkers, J.C.M., 2011. Effect of selection for residual feed intake on feeding behavior and daily feed intake patterns in Yorkshire swine. J. Anim. Sci. 89, 639-647. DOI: 10.2527/jas.2010-2892

Zhang, F. \& Adeola, O., 2017. Techniques for evaluating digestibility of energy, amino acids, phosphorus, and calcium in feed ingredients for pigs. Anim. Nutr. 3(4), 344-352. https://doi.org/10.1016/j.aninu.2017.06.008 